\title{
Physiological characteristics of wild Atlantic salmon post-smolts during estuarine and coastal migration
}

\author{
S. O. Stefansson*†, B. Th. Buörnssont, K. Sundellt, \\ G. NyHAMmer* AND S. D. MCCORMICK \\ * Department of Fisheries and Marine Biology, University of Bergen, Bergen High \\ Technology Centre, N-5020 Bergen, Norway, \$Fish Endocrinology Laboratory, \\ Department of Zoology, Göteborg University, Box 463, S-40530 Göteborg Sweden \\ and $\S U S G S$, Leetown Science Center, Conte Anadromous Fish Research Center, \\ P. O. Box 796, Turners Falls, MA, 01376, U.S.A.
}

(Received 2 December 2002, Accepted 15 July 2003)

\begin{abstract}
Changes were measured in some of the major physiological variables associated with seawater adaptability, growth and energetics in wild Atlantic salmon Salmo salar smolts and post-smolts migrating from the river and through the estuary, fjord and coastal areas in the River Orkla and the Trondheimsfjord, Norway during late May to early June. Gill $\mathrm{Na}^{+}, \mathrm{K}^{+}$-ATPase activity increased to levels of $12-16 \mu \mathrm{mol}$ ADP mg protein ${ }^{-1} \mathrm{~h}^{-1}$ in post-smolts caught in higher salinity zones, probably representing long-term levels of Atlantic salmon post-smolts in oceanic conditions. Muscle moisture was regulated within narrow limits (77.7-78.7\%) in fish from all zones during both years, suggesting that post-smolts adapt to marine conditions without any long-term disturbance of hydro-mineral balance. Lipid and glycogen content showed a general trend towards depletion from the river, through the fjord and into the ocean. There was, however, no significant change in protein content. The present results confirm that smolts are naturally 'energy deficient' during downstream migration, and suggest that post-smolts also mobilize energy reserves during their early marine phase, while protein is allocated for somatic growth. Plasma growth hormone (GH) levels increased transiently during passage through the estuary and fjord, with lower levels observed in post-smolts caught off-shore, i.e. in fish which were feeding on marine prey and had adapted to the marine environment. These physiological changes may confer substantial selective advantages during the critical early marine phase of anadromous salmonids, and hence are adaptive for long-term survival in sea water.

(C) 2003 The Fisheries Society of the British Isles
\end{abstract}

Key words: energetics; growth hormone; $\mathrm{Na}^{+}, \mathrm{K}^{+}$-ATPase; post-smolt; Salmo salar.

\section{INTRODUCTION}

Following parr-smolt transformation and downstream migration, anadromous Atlantic salmon Salmo salar L. often move through complex estuarine and coastal environments before reaching the open ocean. The Norwegian fjords, long and narrow and often with a threshold at the fjord mouth, represent an

\$Author to whom correspondence should be addressed. Tel.: +4755584470 ; fax: +4755584450 ; email: sigurd.stefansson@ifm.uib.no 
important type of confined coastal environment. Although knowledge about the ecology of wild Atlantic salmon post-smolts is quite limited, post-smolts often stay $<1$ month in the fjords and coastal waters after leaving the river (Hvidsten \& Lund, 1988; Thorpe, 1994; M. Holm, I. Huse, E. Waatevik, K.B. Døving \& J. Aure, pers. comm.). Atlantic salmon post-smolts frequently migrate through the fjords or sea lochs in small schools at about the same speed as the surface current, staying most of the time in the upper water-layers (Dutil \& Coutu, 1988; Thorpe, 1994; M. Holm, I. Huse, E. Waatevik, K.B. Døving \& J. Aure, pers. comm.). During this migration from the river through the estuary, fjord and coastal areas, the diet of Atlantic salmon post-smolts changes, and evidence suggests that post-smolts show a certain degree of selective feeding on advantageous prey (Andreassen et al., 2001). Feeding conditions and early marine growth have been postulated to be critical to overall marine survival and year-class strength for Atlantic and Pacific salmonids (Friedland et al., 2000).

Many physiological changes which are adaptive for seawater entry occur in smolts during the downstream migration (Hoar, 1988), and further changes take place in response to seawater transfer (McCormick et al., 1985, 1989; McCormick, 1995; Handeland et al., 1996, 1998, 2000; Björnsson, 1997; Björnsson et al., 1998; Sundell et al., 2003). These physiological responses may be a critical part of the adaptive process to ocean conditions and confer substantial selective advantages during the critical early marine phase of anadromous salmonids (Levings et al., 1994; Andreassen et al., 2001). In spite of this, information on potential physiological and endocrine changes in wild salmonids during the early marine (coastal) phase is virtually non-existent. It is hypothesised that significant physiological adjustments are made during this period, concurrent with changes in behaviour and feeding. The objective of this study was therefore to examine several important physiological variables associated with seawater adaptability, growth and energetics, as well as one of the major endocrine regulators of these processes, growth hormone $(\mathrm{GH})$, in wild migrating Atlantic salmon smolts and post-smolts from the river through the estuary, fjord and coastal areas.

\section{MATERIALS AND METHODS}

\section{STUDY AREA AND FISH}

The study was carried out in the River Orkla and the Trondheimsfjord in central Norway (Fig. 1). Each spring, an estimated 580000 smolts (95\% CI $=300000-1 \cdot 3$ million; N.A. Hvidsten, pers. com.) migrate from the surrounding rivers through the fjord (Levings et al., 1994; Andreassen et al., 2001). The extensive smolt migration and the topography of the Trondheimsfjord make this a well-suited system for studies of postsmolts during the early marine phase. Smolt migration in the River Orkla normally occurs from mid-May to the first week of June, coinciding with peaks in runoff (Hvidsten et al., 1995a). Wild post-smolts were sampled during 2 years, in 1996 from 23 May to 3 June, and in 1997, from 28 May to 3 June (Table 1). Smolts were trapped in the River Orkla at Meldal (defined as zone 0), c. $40 \mathrm{~km}$ from the estuary. River temperature was c. $3 \cdot 5-5^{\circ} \mathrm{C}$ and runoff between 180 and $330 \mathrm{~m}^{3} \mathrm{~s}^{-1}$. The trap consisted of a $1 \mathrm{~m}^{2}$ steel frame opening with a net pouch of mesh size $10 \mathrm{~mm}$ (Granås \& Hvidsten, 1985). Since smolts in the River Orkla are known to migrate nocturnally, the trap was lowered into the river with wire and winch at the Meldal Bridge during twilight and dark hours 


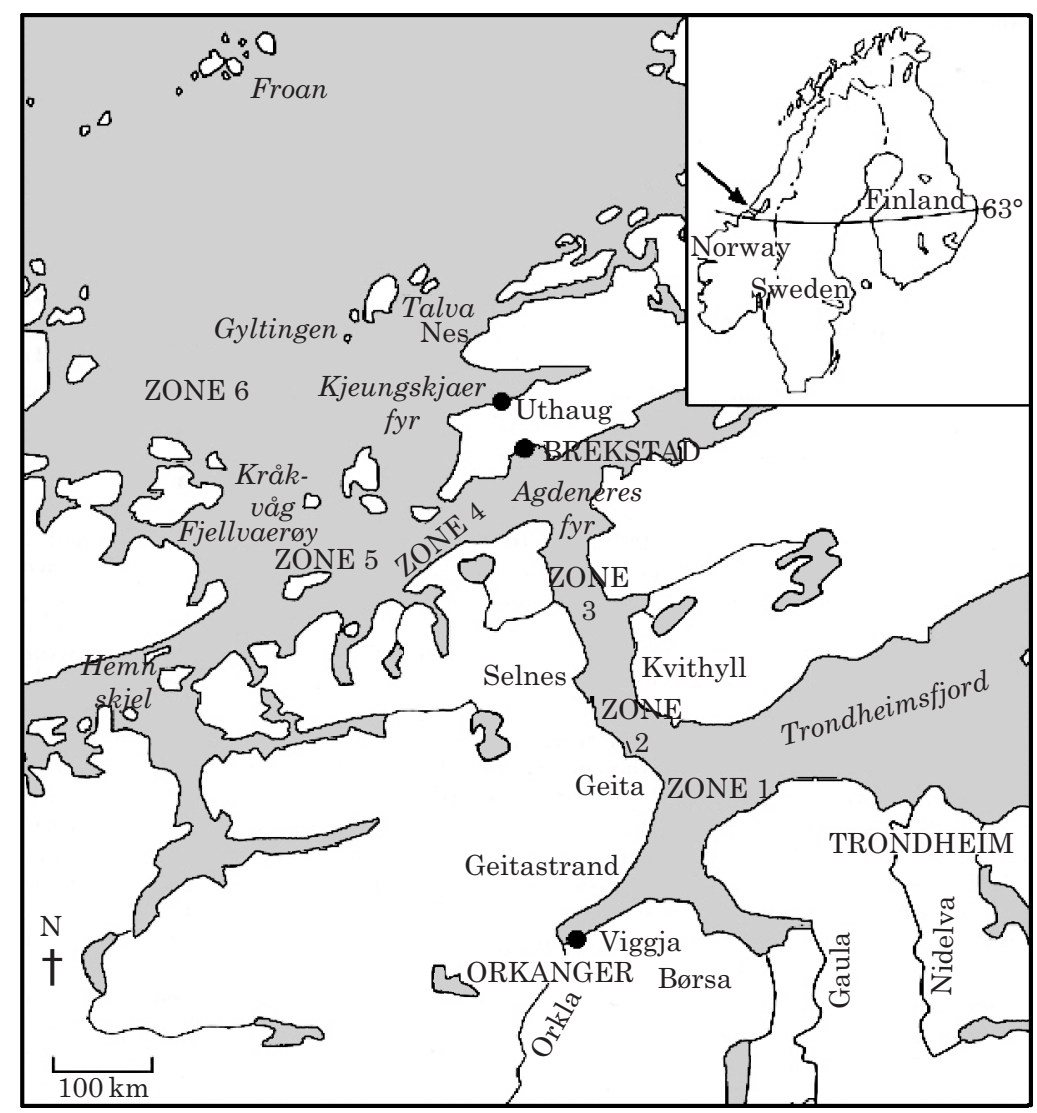

FIG. 1. Map of the study area, the Trondheimsfjord and Frohavet, with the geographical locations of six zones mentioned in the text. (Modified from Andreassen et al., 2001).

(2300-0300 hours) and checked approximately every hour. Immediately after lifting the trap, smolts were transferred to a container filled with river water, transported live to the laboratory and sampled as described below. Sampling began within 6-8 min after smolts had been removed from the trap. Smolts with major scale losses were excluded.

Post-smolts were caught in the sea from the Orkla Estuary through the fjord and into the offshore coastal areas during the sampling conducted by Andreassen et al. (2001; zones 1-6, Fig. 1). The trawl was $36 \mathrm{~m}$ long with a $36 \mathrm{~m}^{2}$ opening, with mesh size $24 \mathrm{~mm}$ in the trawl wings and $8 \mathrm{~mm}$ in the cod-end. The trawl was hauled by two fishing vessels at a speed of $2.78 \mathrm{~km} \mathrm{~h}^{-1}(1.5 \mathrm{knots})$. This method has been used successfully to catch migrating Atlantic salmon post-smolts (Levings et al., 1994; Andreassen et al., 2001). Recently, video observations during trawling have demonstrated that post-smolts are able to sustain the trawling speed, maintaining position inside the trawl for extended periods of time, suggesting that capture stress is not a major concern (M. Holm \& J. Chr. Holst, pers. comm.). Every hour, a smaller boat was used to inspect the codend. If post-smolts were present, they were brought live onboard one of the vessels and sampled. Time between catch and sampling was the same as described for smolts. Fish with extensive scale losses were excluded. All trawling was done during daytime hours (Andreassen et al., 2001). In 1996 post-smolts were caught in zones 2 and 3, and in 1997 in zones $1,3,5$ and 6 (Table I). Salinity of the upper layers $(1-5 \mathrm{~m})$ was similar between years, and increased from the Orkla estuary (5-25 in zone 1, increasing rapidly with depth) to the outer parts of the Trondheimsfjord (21-25 in zone 3) and into Frohavet 


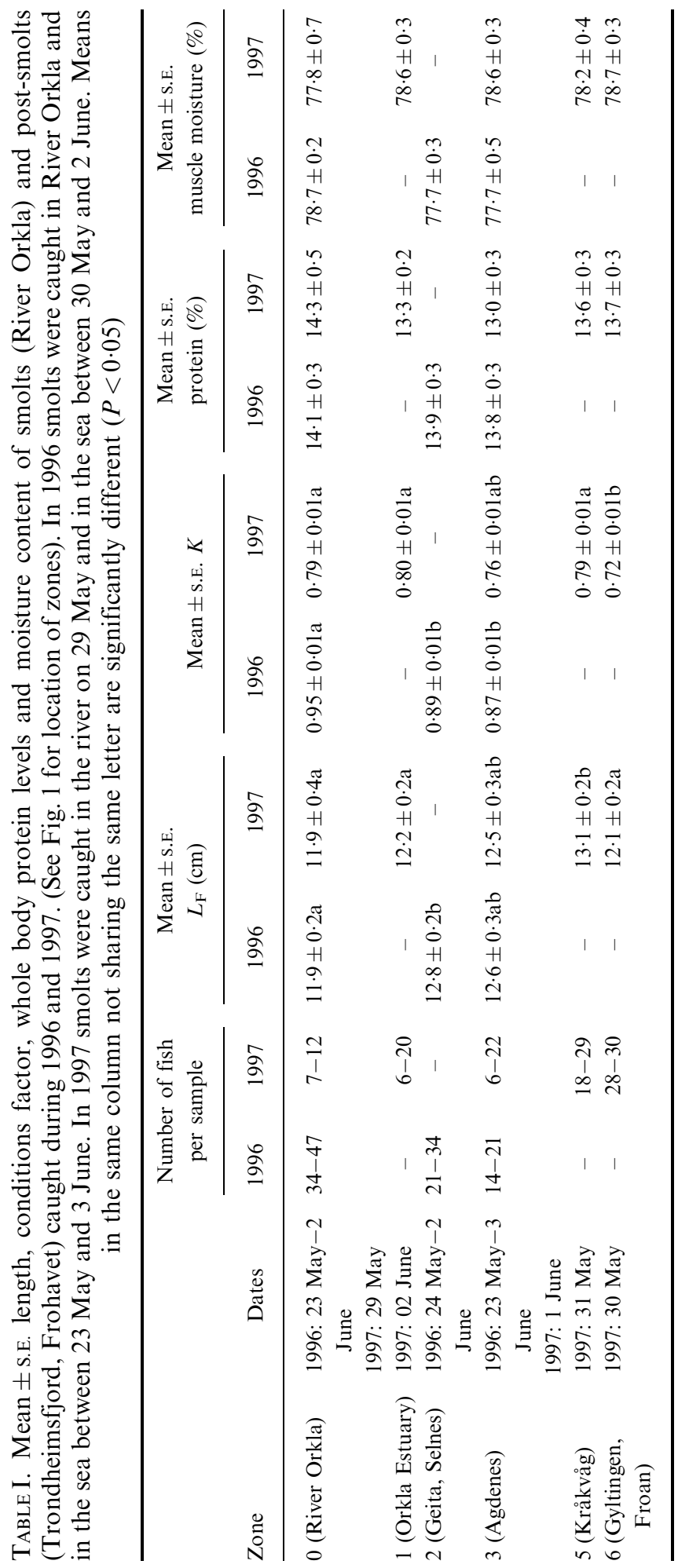


(28-32 in zone 5 and 32-33 in zone 6). There was a distinct halocline and thermocline at $5-7 \mathrm{~m}$ depth in the fjord (zones $1-3$ ), with salinities $>30$ below $7 \mathrm{~m}$. Salinity was more uniform in Frohavet (zones 5,6), characteristic of well-mixed oceanic conditions. The temperature did not differ between years, and was highest in the surface layers $(1-5 \mathrm{~m}$, $7 \cdot 5-10 \cdot 5^{\circ} \mathrm{C}$ ). Beneath the thermocline, the water temperature was stable at $6 \cdot 5-7 \cdot 0^{\circ} \mathrm{C}$. Oxygen levels were $11.1 \mathrm{mgl}^{-1}$ in the upper $1-4 \mathrm{~m}$ and gradually decreased with depth over the next $10 \mathrm{~m}$ to stabilize at $8.6 \mathrm{mgl}^{-1}$.

\section{SAMPLING AND ANALYSIS}

Fish were held in a covered tank with either river water (smolts) or sea water (postsmolts) of ambient salinity until sampling. Fish were killed by a blow to the head, and blood immediately collected from the caudal vessels using $1 \mathrm{ml}$ heparinized syringes. Plasma was separated by centrifugation, frozen on dry ice and stored at $-80^{\circ} \mathrm{C}$ for subsequent growth GH analysis. All fish were weighed (wet mass, $M$ ) and measured (fork length, $\left.L_{\mathrm{F}}\right)$ and the condition factor $(K)$ was calculated $\left.\left(K=100 M L_{\mathrm{F}}^{-3}\right)\right)$. The second gill arch on the left side was dissected out, immersed in SEI buffer $(150 \mathrm{mM}$ sucrose, $10 \mathrm{mM}$ $\mathrm{Na}_{2}$-EDTA, $50 \mathrm{mM}$ imidazole at $\mathrm{pH} 7 \cdot 3$ ), frozen on dry ice and stored at $-80^{\circ} \mathrm{C}$ until analysis of $\mathrm{Na}^{+}, \mathrm{K}^{+}$-ATPase activity. The body cavity was opened ventrally and the intestine, from just posterior to the last pyloric caeca to the anus, was carefully removed. It was then cut open along the mesenteric border, carefully rinsed in physiological saline $(0.9 \% \mathrm{NaCl})$ and the mucosa scraped off using two glass microscope slides. The mucosal scrapings were placed in ice-cold intestinal buffer $(200 \mathrm{mM}$ glycine, $300 \mathrm{mM}$ sucrose, $45 \mathrm{mM} \mathrm{Na}{ }_{2}$-EDTA, $50 \mathrm{mM}$ EGTA, $50 \mathrm{mM}$ imidazole at $\mathrm{pH} 7 \cdot 6$ ), immediately frozen on dry ice and stored at $-80^{\circ} \mathrm{C}$ for later analysis of intestinal $\mathrm{Na}^{+}, \mathrm{K}^{+}$-ATPase activity. The stomach was removed for prey analysis (Andreassen et al., 2001). The carcasses, including all other organs were frozen at $-20^{\circ} \mathrm{C}$ for subsequent analyses of protein and lipid levels, moisture content, liver mass $\left(M_{\mathrm{L}}\right)$ and glycogen contents. The liver somatic index $\left(I_{\mathrm{L}}\right)$ was calculated: $I_{\mathrm{L}}=100 M_{\mathrm{L}} M^{-1}$.

Plasma GH levels were determined by a specific salmon GH radioimmunoassay (Björnsson et al., 1994). Due to small plasma volumes, readings outside of the standard curve could not be re-run with diluted plasma. These samples were assigned the concentration of the highest standard $\left(50 \mathrm{ng} \mathrm{ml}^{-1}\right)$, and thus underestimated the true value. This was most pronounced in samples from zones 3 (13 of 22) and 5 (14 of 29) in 1997.

Gill filaments and intestinal scrapings were thawed on the day of assay, the storage buffer discarded, and gill $\mathrm{Na}^{+}, \mathrm{K}^{+}$-ATPase activity analysed according to McCormick (1993). Intestinal scrapings were homogenized in $800 \mu$ intestinal buffer (containing $0.3 \mathrm{mM}$ PMSF and $0.34 \mathrm{ml}$ aprotinin $100 \mathrm{ml}$ buffer $^{-1}$ ) using a glass/glass tissue grinder (Contes, Vineland, NJ, U.S.A.). The homogenized samples were centrifuged at $5000 \mathrm{~g}$ for $30 \mathrm{~s}$. Ten $\mu \mathrm{l}$ of the supernatant were added, in duplicate, to wells of a 96-well microplate containing $200 \mu \mathrm{l}$ assay medium, with and without $0.5 \mathrm{mM}$ ouabain, and read at $340 \mathrm{nM}$ for $10 \mathrm{~min}$ at $25^{\circ} \mathrm{C}$. Protein concentrations of intestinal homogenates were assessed according to Lowry et al. (1951). $\mathrm{Na}^{+}, \mathrm{K}^{+}$-ATPase activity was expressed as $\mu$ mol ADP mg protein ${ }^{-1} \mathrm{~h}^{-1}$.

Frozen carcasses were thawed and homogenised in one volume of deionised water. Total lipid was extracted and moisture content measured immediately, while protein and glycogen aliquots were frozen for later assay. Moisture, lipid, protein and glycogen were measured as outlined in Leonard \& McCormick (1999). Briefly, lipids were extracted from $1 \mathrm{ml}$ of homogenate with 20 volumes of $1: 1$ chloroform : methanol. Extracted lipid was spectrophotometrically determined using the phosphovanillin method with extracted and gravimetrically quantified cod liver oil as standard. Protein was quantified using the folin-phenol reagent with bovine serum albumin as standard. Moisture content was measured by drying $1 \mathrm{~g}$ of homogenized tissue to a constant (dry) mass at $60^{\circ} \mathrm{C}$ for $24 \mathrm{~h}$. Glycogen samples were digested with amyloglucosidase for $2 \mathrm{~h}$ at $55^{\circ} \mathrm{C}$, and glucose in digested and undigested samples were assayed using the glucose-o-dianisidineperoxidase reaction. 


\section{STATISTICS}

All statistical analyses were performed with Statistica 5.0 (StatSoft, 1997). A Kolmogorov-Smirnov test was used to assess normality of distributions, and homogeneity of variances was tested using Levene's $F$-test (Zar, 1996). With the exception of GH data from 1997 (skewed distributions), all variables were in accordance with the requirements for parametric tests (Zar, 1996). As differences in body size were found between zones (Table I), data were tested using a one-way ANCOVA with $L_{\mathrm{F}}$ as a co-variate. Significant ANCOVAs were followed by Tukey's HSD test for unequal $n$ (Zar, 1996). GH data from 1997 were tested in a Kruskal-Wallis ANOVA by ranks followed by Mann-Whitney $U$-tests, using Bonferroni adjusted $P$-levels (Zar, 1996). A significance level of 0.05 was used. Data are presented as mean \pm S.E.

\section{RESULTS}

In 1996, post-smolts caught in zone 3 had a higher mean $L_{F}$ than smolts caught in the river (Table I). In 1997, the post-smolts in zone 5 were longer than fish caught in the river or other zones (Table I). The condition factor of the fish was higher (0.87-0.95) in 1996 than in 1997 (0.72-0.80), with a significant reduction from fresh water to sea water in both years (Table I).

There were no significant differences in gill $\mathrm{Na}^{+}, \mathrm{K}^{+}$-ATPase activity of fish caught in zones 0, 2 and 3 in 1996, with levels in the range 8.3-8.7 $\mu$ mol ADP $\mathrm{mg}$ protein ${ }^{-1} \mathrm{~h}^{-1}$ [Fig. 2(a)]. In 1997, levels in fish caught in the river and the estuary (zones 0 and 1) were similar to those observed in 1996. Unlike the year before, however, in 1997 gill $\mathrm{Na}^{+}, \mathrm{K}^{+}$-ATPase activity of fish in zone 3 was significantly higher than that of fish in the inner zones. Peak levels were observed in zone $5\left(16 \mu \mathrm{mol}\right.$ ADP $\mathrm{mg}$ protein $\left.^{-1} \mathrm{~h}^{-1}, P<0 \cdot 05\right)$ with slightly lower activity in zone 6 . In both years, no significant changes were observed in intestinal $\mathrm{Na}^{+}, \mathrm{K}^{+}$-ATPase activity between the different zones [Fig. 2(b)]. Overall, the intestinal enzyme activity was higher in $1996(0 \cdot 9-1 \cdot 2 \mu \mathrm{mol}$ ADP mg protein $\left.{ }^{-1} \mathrm{~h}^{-1}\right)$ than in $1997\left(0 \cdot 6-0 \cdot 75 \mu \mathrm{mol}\right.$ ADP $\mathrm{mg}$ protein $\left.{ }^{-1} \mathrm{~h}^{-1}\right)$.

Mean plasma growth hormone levels in smolts caught in the River Orkla were $15 \cdot 4 \mathrm{ng} \mathrm{ml}^{-1}$ in 1996 and $35 \cdot 2 \mathrm{ng} \mathrm{ml}^{-1}$ in 1997 [Fig. 2(c)]. Plasma GH levels increased in zones 2 (1996) and 3 (1997) to comparable levels of $40-45 \mathrm{ng} \mathrm{ml}^{-1}$. Due to assay limitations (see Materials and methods), these levels were probably a slight underestimate. In 1997, the lowest plasma GH levels (significantly lower than for fish in all other zones) were observed in zone 6, i.e. in fully marine conditions [Fig. 2(c)].

In both years, the $I_{\mathrm{L}}$ was within the same range of $0 \cdot 6-1 \cdot 0 \%$ [Fig. 3(a)], and was higher for smolts in the River Orkla (zone 0) than for fish in the estuary and fjord (zones 2, 3 in 1996, and 5 in 1997). In 1997, when samples were obtained from off-shore, fully marine conditions (zone 6), a significant increase in $I_{\mathrm{L}}$ was observed.

Lipid and glycogen content decreased significantly in zone 6 and glycogen showed a general trend towards depletion as fish moved from the river, through the Trondheimsfjord and out into the ocean [Fig. 3(b), (c)]. Protein levels did not differ significantly among zones (Table I). Moisture content (Table I) did not change significantly, and appeared to be tightly regulated in the range $77 \cdot 7-78 \cdot 7 \%$ in fish from all zones during both years. 

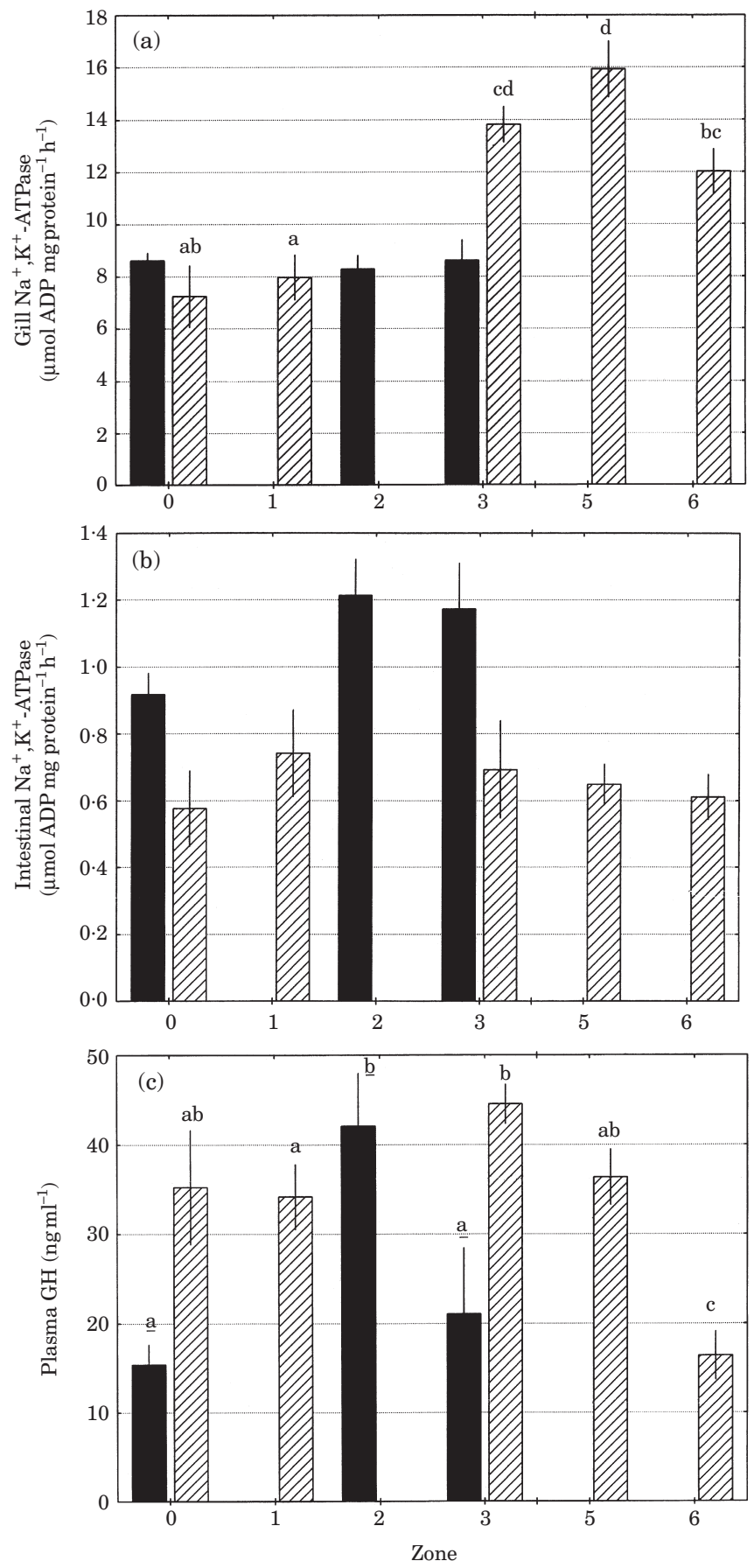

Fig. 2. Mean \pm S.E. (a) gill and (b) intestinal $\mathrm{Na}^{+}, \mathrm{K}^{+}$-ATPase activity, and (c) circulating growth hormone levels in smolts from the River Orkla (zone 0 ) and post-smolts from the Trondheimsfjord and Frohavet (see Fig. 1) in $1996(\mathbf{\square})$ and $1997(\mathbb{Z}) . n \geq 12$ with the following exceptions (1997; see Table I): GH, zone $0, n=7$; intestinal $\mathrm{Na}^{+}, \mathrm{K}^{+}$-ATPase, zones 1 and $3, n=6$. Values not sharing the same letter (underlined for 1996) are significantly different $(P<0 \cdot 05)$. 

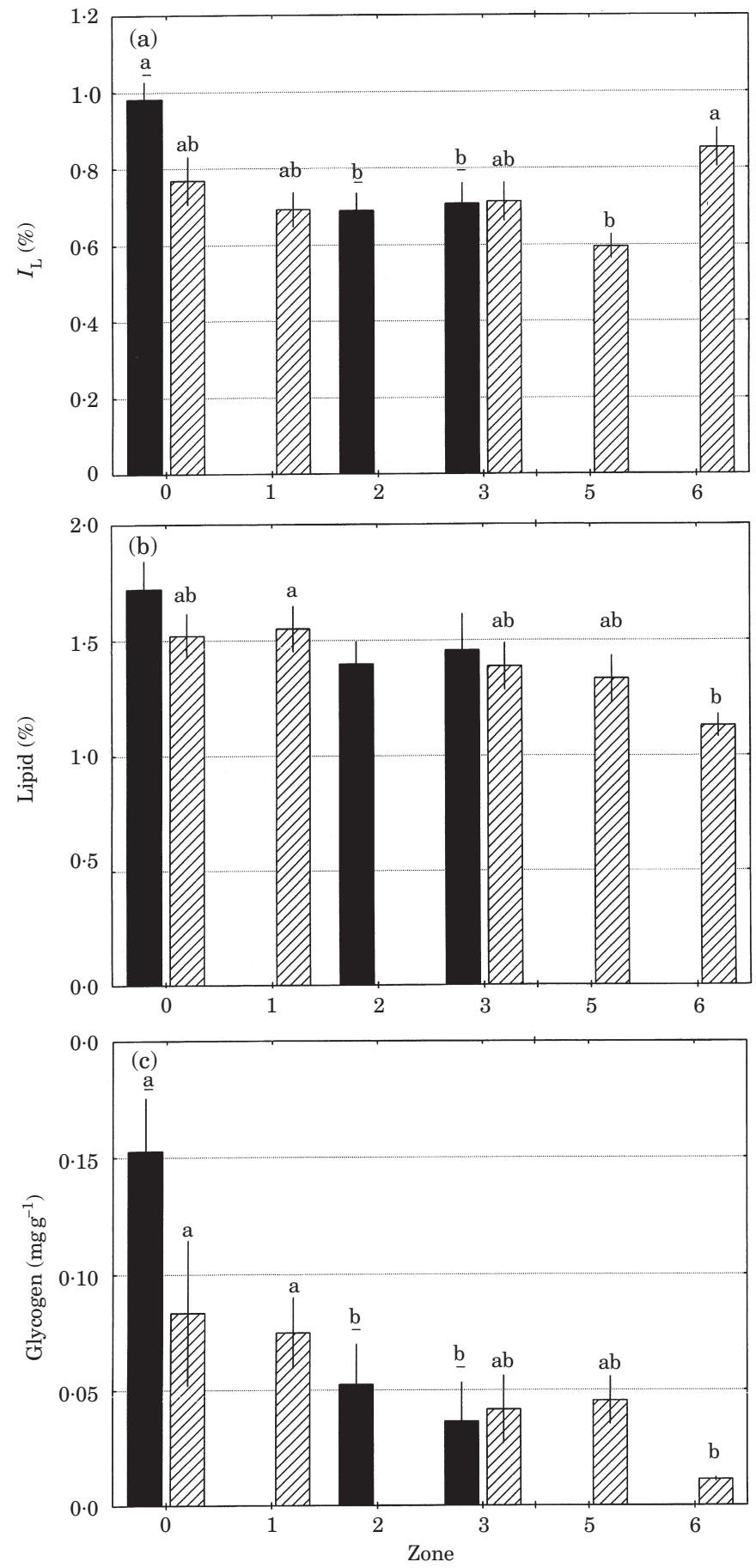

FIG. 3. Mean \pm s.e. (a) liver-somatic index, (b) lipid content and (c) glycogen levels in smolts from the River Orkla (zone 0) and posts-molts from the Trondheimsfjord and Frohavet (see Fig. 1) in 1996 (ם) and $1997(\square) . n \geq 16$, except for zone 0, $1997(n=12)$. Values not sharing the same letter (underlined for 1996) are significantly different $(P<0 \cdot 05)$. 


\section{DISCUSSION}

The present study represents findings during the peak of the smolt run in the Trondheimsfjord region (Hvidsten et al., 1995a) during two consecutive years. Self-sustaining Atlantic salmon populations are found in more than 25 rivers draining to the Trondheimsfjord (Johnsen et al., 1999), and each spring, large numbers of smolts migrate from these rivers through the fjord (Levings et al., 1994). This extensive smolt migration and the topography of the Trondheimsfjord make this a particularly well-suited system for studies of Atlantic salmon postsmolts in estuaries, fjords and coastal conditions. Smolts caught in the river and estuary (zone 1) most likely originate from the River Orkla. Further out into the fjord and offshore, post-smolts from Rivers Gaula, Nidelva, Verdalselva, Stjørdalselva and Surna, to name the most important, probably form mixed schools during their ocean migration. Post-smolts which were caught in zones 2 to 6 most likely represent earlier segments of the smolt run from several rivers, than the fish caught closer to the River Orkla. It should be noted, however, that all other major rivers which are likely to contribute significantly to catches in the outer zones are all located further in along the Trondheimsfjord or large distances south along the coast. Therefore, while it is possible to view the present data as a simple developmental series of changes during smolt migration from the river, through the estuary and fjord, out to the open sea and full oceanic conditions, this interpretation has to be made with caution, as fish may be arriving in the outer zones from different rivers, representing different segments of the smolt run, and having spent different periods of time in sea water. Handeland et al. (2000) suggested that smolts are physiologically adapted to sea water after $c .4$ days at temperatures similar $\left(9^{\circ} \mathrm{C}\right)$ to those in the present study. Based on tracking studies in the Trondheimsfjord suggesting an overall average migration speed of 2 body lengths $\mathrm{s}^{-1}$ (Hvidsten et al., 1995b; M. Holm, pers. comm.), supported by studies of diet and prey selection (Andreassen et al., 2001), it is reasonable to assume that the smolts caught in zone 1 are adapting to estuarine conditions. Accordingly, fish caught in zones 5 and $6(c .100 \mathrm{~km}$ from the Orkla Estuary, having spent at least 5 days in coastal waters) have to a large extent adapted to marine conditions, whereas some inter-individual variation in seawater adaptation would be expected in post-smolts caught in zones 2 and 3 .

There are few published data from the early marine phase of Atlantic salmon with which to compare the present findings. McCormick \& Björnsson (1994) described physiological characteristics of wild and hatchery-reared Atlantic salmon parr and smolts from the Connecticut River. The present results on gill $\mathrm{Na}^{+}, \mathrm{K}^{+}$-ATPase activity in smolts from the River Orkla are in the same range as those reported by McCormick \& Björnsson (1994), Handeland et al. (1998) and Stefansson et al. (1998). Gill $\mathrm{Na}^{+}, \mathrm{K}^{+}$-ATPase activity increased significantly in post-smolts caught in higher salinity zones (zones 3-6, 1997), in line with results obtained in smolts exposed to full-strength sea water under laboratory conditions (Berge et al., 1995; Handeland et al., 1998, 2000) and Atlantic salmon and brook trout Salvelinus fontinalis (Mitchill) caught in estuarine conditions (McCormick et al., 1985). As noted above, zone 3 probably represents an area with some temporal variation in seawater adaptation during 
the course of the smolt run and between years, hence some variation is to be expected. Overall gill enzyme activity levels in smolts from the higher salinity zones are similar to levels observed in hatchery post-smolts after 2-4 weeks of exposure to full-strength sea water at corresponding temperatures (Handeland et al., 1998, 2000), and probably represent long-term branchial $\mathrm{Na}^{+}, \mathrm{K}^{+}$-ATPase activity of Atlantic salmon post-smolts under oceanic conditions (salinity 33-35, $8-10^{\circ} \mathrm{C}$ ). The salmonid intestine increases its fluid uptake during the parr-smolt transformation, as a preparatory adaptation to its role as a water-absorbing organ in sea water (Veilette et al., 1995). The major driving force behind this intestinal fluid transport is the $\mathrm{Na}^{+}, \mathrm{K}^{+}$-ATPase located in the enterocytes (Loretz, 1995). Accordingly, this enzyme activity increases during the parrsmolt transformation (Sundell et al., 2003). The present results do not lend unequivocal support to these observations, however, the tendency of increased intestinal $\mathrm{Na}^{+}, \mathrm{K}^{+}$-ATPase activity in the fish caught further out in the estuary (zones 2 and 3 in 1996) is in line with earlier studies on Atlantic salmon postsmolts, which show that intestinal $\mathrm{Na}^{+}, \mathrm{K}^{+}$-ATPase activity continues to increase after transfer to sea water (Sundell et al., 2003). Muscle moisture was regulated within narrow limits $(77 \cdot 7-78 \cdot 7 \%$, Table I) in fish from all zones during both years, suggesting that the post-smolts were fully competent osmoregulators, able to adapt to marine conditions without any long-term disturbance of hydro-mineral balance. The present levels are consistent with observations of muscle moisture in seawater acclimated post-smolts under laboratory conditions (Handeland et al., 2000).

Smolt development is normally accompanied by decreases in lipid reserves and liver glycogen, even when fishes are fed ad libitum (Sheridan, 1989). This has led to the general concept that smolts are naturally 'energy deficient' during the downstream migration. The present results support this hypothesis and indicate that smolts also have low energy reserves during the early marine phase. There was, however, no significant change in protein content, and even a tendency of an increase from the estuary and off-shore in 1997. Taken together, the present findings indicate that post-smolts maintain a positive protein balance, and that there is a high scope for growth during this period, at the expense of energy stores and in spite of their low mass-specific energy content. This hypothesis is consistent with increasing RNA : DNA ratios in wild post-smolts from estuary through fjords and into the ocean (S.O. Stefansson, P.A. Bjørn, B. Finstad \& N.A. Hvidsten, unpubl. data).

The physiological changes taking place during the early phase of the Atlantic salmon ocean migration as seen in this study, i.e. high hypo-osmoregulatory capacity, growth and energy mobilization, are all processes that are likely to be stimulated by growth hormone (Björnsson, 1997). Such activation of the GH system is indicated by the relatively high plasma GH levels seen in the downstream migrating smolts in the river as well as in fish in the coastal zones $(1,2,3$ and 5). Although plasma GH levels increase during smoltification, levels as high as $35-45 \mathrm{ng} \mathrm{ml}^{-1}$ are rarely seen in smolting Atlantic salmon in aquaculture. McCormick \& Björnsson (1994), however, have reported even higher levels (75$100 \mathrm{ng} \mathrm{ml}^{-1}$ ) from wild Atlantic salmon smolts during migration in the Connecticut River. Thus, the present data support the notion that there are significant differences in the degree of activation of the $\mathrm{GH}$ system between the 
wild and farmed salmonids in the freshwater environment, as has been seen for smoltifying brown trout Salmo trutta L. (Sundell et al., 1998). This is also demonstrated by increased plasma GH levels after release of hatchery-reared salmonids into the natural environment [Atlantic salmon, McCormick et al., 2002; Amago salmon Oncorhynchus rhodurus (Günther), Munakata et al., 2000] or semi-natural environment [steelhead trout Oncorhynchus mykiss (Walbaum), Zydlewski et al., 2003).

Although it is likely that the capture method used resulted in both 'exercise' and 'stress' responses, it is considered unlikely that these had a significant impact on the variables measured in this study. Stress and exhaustive exercise apparently do not affect muscle moisture content of salmonids (Wang et al., 1994). Although the response of gill $\mathrm{Na}^{+}, \mathrm{K}^{+}$-ATPase activity to stress is variable among experiments, the time course that has been observed for any response to stress is much longer than would have affected fish in the present study (McCormick, 1995). A 'chasing' stress has been shown to result in decreased plasma GH levels in salmonids (Farbridge \& Leatherland, 1992), whereas 'sustained exercise' results in elevated plasma GH (Nielsen et al., 1994). In each of these cases, however, the time necessary to achieve changes in plasma $\mathrm{GH}$ is greater than the time fish would have been exposed to stress or exercise during capture in the present study. In addition, the within group variation in plasma $\mathrm{GH}$ was relatively small; this also indicates that stress or exercise is not a major determinant of plasma GH levels, as the trawled fish are likely to have been exposed to highly varying period of stress and exercise.

Under controlled conditions, plasma GH levels of salmonids show a significant, transient increase following seawater transfer (Björnsson, 1997), with salinity and temperature as modulating factors (Björnsson et al., 1998; Handeland et al., 1998, 2000). This transient response is reflected by the highest plasma GH levels observed in fish caught in zones 2 (1996) and 3 (1997). Accordingly, Stefansson et al. (1991) reported low plasma GH levels $\left(<5 \mathrm{ng} \mathrm{ml}^{-1}\right)$ in actively feeding, rapidly growing cultured Atlantic salmon in sea water. These findings correspond well with the lower $\mathrm{GH}$ levels $\left(16 \mathrm{ng} \mathrm{ml}^{-1}\right)$ in fish caught in zone 6 in 1997, as these fish were feeding actively (high fullness index, high forage ratio and no empty stomachs) almost exclusively on marine prey (Copepoda, Euphausiidae, Zoea), and seemed well adapted to the marine environment (Andreassen et al., 2001). Such decreases in GH levels following seawater adaptation are not, however, interpreted as a down-regulation of the GH system, but rather activation, with concurrent increases of both secretion and metabolic clearance rates, resulting in a relatively low 'set-point' for the plasma GH levels (Sakamoto et al., 1990; Sakamoto \& Hirano, 1991; Agustsson et al., 2001). As with earlier data from laboratory experiments, it can only be speculated whether such activation of the GH system in sea water is related to the role of $\mathrm{GH}$ in osmoregulation, growth regulation or both. Since the early marine growth of smolts has been strongly linked to overall marine survival, the role of increased growth hormone as it relates to growth and energy utilization during this phase bears further investigation.

The present study has shown that there are several physiological changes that accompany the voluntary migratory movement of smolts from fresh to sea water. Entry into fjords and the ocean is associated with continued increases 
in gill $\mathrm{Na}^{+}, \mathrm{K}^{+}$-ATPase activity and decreased lipid content. Plasma growth hormone levels increased transiently during passage through the fjord, with a decline in post-smolts in the ocean. These physiological changes may be a critical part of the adaptation to ocean conditions and are probably adaptive for long-term survival of Atlantic salmon in sea water.

We thank N. A. Hvidsten, Norwegian Institute of Nature Research, and P.M.R. Andreassen, K. Pettersen, B. Sveinsbø at University of Bergen for access to the fish material and assistance during sampling. We thank B. Egnér, Göteborg University for the GH assay work. We thank T. Dubreuil and J. Carey at the Conte Laboratory for running the lipid and protein assays. This study was partly funded by the Research Council of Norway and the Swedish Council for Agricultural and Forestry Research.

\section{References}

Agustsson, T., Sundell, K., Sakamoto, T., Johansson, V., Ando, M. \& Björnsson, B. Th. (2001). Growth hormone endocrinology of Atlantic salmon: Pituitary gene expression, hormone storage, secretion, and plasma levels during parr-smolt transformation. Journal of Endocrinology 170, 227-234.

Andreassen, P. M. R., Martinussen, M. B., Hvidsten, N. A. \& Stefansson, S. O. (2001). Feeding and prey-selection of wild Atlantic salmon post-smolts. Journal of Fish Biology 58, 1667-1679. doi: 10.1006/jfbi.2001.1576.

Berge, A. I., Berg, A., Fyhn, H. J., Barnung, T., Hansen, T. \& Stefansson, S. O. (1995). Development of salinity tolerance in underyearling smolts of Atlantic salmon (Salmo salar L.) reared under different photoperiods. Canadian Journal of Fisheries and Aquatic Sciences 52, 243-251.

Björnsson, B. Th. (1997). The biology of salmon growth hormone: from daylight to dominance. Fish Physiology and Biochemistry 17, 9-24.

Björnsson, B. Th., Stefansson, G. V., Berge, Å. I., Hansen, T. \& Stefansson, S. O. (1998). Circulating growth hormone levels in Atlantic salmon following seawater transfer: Effects of photoperiod regime, salinity, duration of exposure and season. Aquaculture 168, 121-137.

Björnsson, B. Th., Taranger, G. L., Hansen, T., Stefansson, S. O. \& Haux, C. (1994). The interrelation between photoperiod, growth hormone and sexual maturation of adult Atlantic salmon (Salmo salar). General and Comparative Endocrinology 93, 70-81.

Dutil, J. D. \& Coutu, J. M. (1988). Early marine life of Atlantic salmon, Salmo salar postsmolts in the Northern Gulf of St. Lawrence. Fishery Bulletin 86, 197-212.

Farbridge, K. J. \& Leatherland, J. F. (1992). Plasma growth hormone levels in fed and fasted rainbow trout (Oncorhynchus mykiss) are decreased following handling stress. Fish Physiology and Biochemistry 10, 67-73.

Friedland, K. D., Hansen, L. P., Dunkley, D. A. \& MacLean, J. C. (2000). Linkage between ocean climate, post-smolt growth, and survival of Atlantic salmon (Salmo salar L.) in the North Sea area. ICES Journal of Marine Science 57, 419-429.

Granås, E. \& Hvidsten, N. A. (1985). The food of Atlantic salmon Salmo salar L. and brown trout Salmo trutta L. smolts during migration in Orkla River, Norway. Fauna Norvegica Serie A 6, 24-28.

Handeland, S. O., Berge, A. I., Björnsson, B. Th. \& Stefansson, S. O. (1998). Effects of temperature and salinity on osmoregulation and growth of Atlantic salmon (Salmo salar L.) smolts in seawater. Aquaculture 168, 289-302.

Handeland, S. O., Berge, A., Björnsson, B. Th., Lie, Ø. \& Stefansson, S. O. (2000). Seawater adaptation of Atlantic salmon (Salmo salar L.) at different temperatures. Aquaculture 181, 377-396. 
Handeland, S. O., Järvi, T., Fernö, A. \& Stefansson, S. O. (1996). Osmotic stress, antipredatory behaviour and mortality of Atlantic salmon (Salmo salar L.) postsmolts. Canadian Journal of Fisheries and Aquatic Sciences 53, 2673-2680.

Hoar, W. S. (1988). The physiology of smolting salmonids. In Fish Physiology, Vol. XIB (Hoar, W. S. \& Randall, D. J., eds), pp. 275-343. New York: Academic Press.

Hvidsten, N. A. \& Lund, R. A. (1988). Predation on hatchery-reared and wild smolts of the Atlantic salmon, Salmo salar L., in the estuary of River Orkla, Norway. Journal of Fish Biology 33, 121-126.

Hvidsten, N. A., Jensen, A. J., Vivås, H., Bakke, Ø. \& Heggberget, T. G. (1995a). Downstream migration of Atlantic salmon smolts in relation to water flow, water temperature, moon phase and social interaction. Nordic Journal of Freshwater Research 70, 38-48.

Hvidsten, N. A., Johnsen, B. O. \& Levings, C. D. (1995b). Vandring og ernæring hos laksesmolt i Trondheimsfjorden og på Frohavet. NINA Oppdragsmelding 332 (in Norwegian).

Johnsen, B. O., Hvidsten, N. A. \& Møkkelgjerd, P. I. (1999). Lakselver i Trondheimsfjorden [Salmon rivers in the Trondheimsfjord]. Norwegian Institute for Nature ResearchNINA Oppdragsmelding 598, 1-38 (with English summary).

Leonard, J. B. K. \& McCormick, S. D. (1999). Effects of migration distance on whole-body and tissue-specific energy use in American shad (Alosa sapidissima). Canadian Journal of Fisheries and Aquatic Sciences 56, 1159-1171.

Levings, C. D., Hvidsten, N. A. \& Johnsen, B. O. (1994). Feeding of Atlantic salmon, Salmo salar post-smolts in a fjord in central Norway. Canadian Journal of Zoology 72, 834-839.

Loretz, C. A. (1995). Electrophysiology of ion transport in teleost intestinal cells. In Cellular and Molecular Approaches to Fish Ionic Regulation (Wood, C. M. \& Shuttleworth, T. J., eds), pp. 25-56. San Diego, CA: Academic Press.

Lowry, O. H., Rosebrough, N. J., Farr, A. L. \& Randall, R. J. (1951). Protein measurement with the folin phenol reagent. Journal of Biological Chemistry 193, 265-275.

McCormick, S. D. (1993). Methods for nonlethal gill biopsy and measurement of $\mathrm{Na}^{+}$, $\mathrm{K}^{+}$-ATPase activity. Canadian Journal of Fisheries and Aquatic Sciences 50, 656-658.

McCormick, S. D. (1995). Hormonal control of gill $\mathrm{Na}^{+}, \mathrm{K}^{+}$-ATPase and chloride cell function. In Cellular and Molecular Approaches to Fish Ionic Regulation (Wood, C. M. \& Shuttleworth, T. J., eds), pp. 285-315. San Diego, CA: Academic Press.

McCormick, S. D. \& Björnsson, B. Th. (1994). Physiological and hormonal differences among Atlantic salmon parr and smolts reared in the wild, and hatchery smolts. Aquaculture 121, 235-244.

McCormick, S. D., Moyes, C. D. \& Ballantyne, J. S. (1989). Influence of salinity on the energetics of gill and kidney of Atlantic salmon (Salmo salar). Fish Physiology and Biochemistry 6, 243-254.

McCormick, S. D., Naiman, R. J. \& Montgomery, E. T. (1985). Physiological smolt characteristics of anadromous and non-anadromous brook trout (Salvelinus fontinalis) and Atlantic salmon (Salmo salar). Canadian Journal of Fisheries and Aquatic Sciences 42, 529-538.

McCormick, S. D., O’Dea, M. F., Moeckel, A. M. \& Björnsson, B. Th. (2002). Endocrine and physiological changes in Atlantic salmon smolts following hatchery release. Aquaculture 222, 45-57.

Munakata, A., Björnsson, B. Th., Jönsson, E., Amano, M., Ikuta, K., Kitamura, S., Kurokawa, T. \& Aida, K. (2000). Post-release adaptation processes of hatchery-reared honmasu salmon parr. Journal of Fish Biology 56, 163-172. doi: 10.1006/jfbi.1999.1147.

Nielsen, M. E., Boesgaard, L., Sweeting, R. M., McKeown, B. A. \& Rosenkilde, P. (1994). Plasma levels of lactate, potassium, glucose, cortisol, growth hormone and triiodo-L-thyronine in rainbow trout (Oncorhynchus mykiss) during exercise at various levels for 24 h. Canadian Journal of Zoology 72, 1643-1647.

Sakamoto, T. \& Hirano, T. (1991). Growth hormone receptors in the liver and osmoregulatory organs of rainbow trout: characterisation and dynamics during adaptation to seawater. Journal of Endocrinology 130, 425-433. 
Sakamoto, T., Ogasawara, T. \& Hirano, T. (1990). Growth hormone kinetics during adaptation to a hyperosmotic environment in rainbow trout. Journal of Comparative Physiology 160, 1-6.

Sheridan, M. (1989). Alterations in lipid metabolism accompanying smoltification and seawater adaptation of salmonid fish. Aquaculture 82, 191-203.

StatSoft (1997). Statistica User's Guide, Version 5.0. Tulsa, OK: Statsoft Inc.

Stefansson, S. O., Berge, A. I. \& Gunnarsson, G. S. (1998). Changes in seawater tolerance and gill $\mathrm{Na}^{+}, \mathrm{K}^{+}$-ATPase activity during desmoltification in Atlantic salmon kept in freshwater at different temperatures. Aquaculture 168, 271-277.

Stefansson, S. O., Björnsson, B. Th., Hansen, T., Haux, C., Taranger, G. L. \& Saunders, R. L. (1991). Growth, parr-smolt transformation and changes in growth hormone of Atlantic salmon (Salmo salar) reared under different photoperiods. Canadian Journal of Fisheries and Aquatic Sciences 48, 2100-2108.

Sundell, K., Dellefors, C. \& Björnsson, B. Th. (1998). Wild and hatchery-reared brown trout, Salmo trutta, differ in smolt related characters during parr-smolt transformation. Aquaculture 167, 53-65.

Sundell, K., Jutfelt, F., Agustsson, T., Olsen, R.-E., Sandblom, E., Hansen, T. \& Björnsson, B. Th. (2003). Intestinal transport mechanisms and plasma cortisol levels during normal and out-of-season parr-smolt transformation of Atlantic salmon, Salmo salar. Aquaculture 222, 265-286.

Thorpe, J. E. (1994). Salmonid fishes and the estuarine environment. Estuaries 17, 76-93.

Veilette, P. A., Sundell, K. \& Specker, J. L. (1995). Cortisol mediates the increase in intestinal fluid uptake in Atlantic salmon during parr-smolt transformation. General and Comparative Endocrinology 97, 250-258.

Wang, Y. X., Heigenhauser, G. J. F. \& Wood, C. M. (1994). Integrated responses to exhaustive exercise and recovery in rainbow trout white muscle: Acid-base, phosphogen, carbohydrate, lipid, ammonia, fluid volume and electrolyte metabolism. Journal of Experimental Biology 195, 227-258.

Zar, J. H. (1996). Biostatistical Analysis. New Jersey: Prentice Hall.

Zydlewski, G. B., Foott, S., Nichols, K., Hamelberg, S., Zydlewski, J. D. \& Björnsson, B. Th. (2003). Enhanced smolt characteristics of steelhead trout exposed to alternative hatchery conditions during the final months of rearing. Aquaculture 222, 101-117. 